\title{
How to Evaluate the Management of Migration Flows to a Region on the Basis of Parameters of the Region's Migration Attractiveness
}

\author{
Daria Grizovskaya* \\ Tver State University, 170100, Tver, Russia
}

\begin{abstract}
Given the decline in the share of the able-bodied population, a large share of low-skilled labor, and the need to implement national projects aimed at changing the demographic background of the state, which are primarily expressed in stimulating the birth rate growth, the Russian Federation is faced with the task of attracting labor migrants capable of supporting the industrial transformation of the Russian economy. The aim of the study is to develop a comprehensive, goaloriented approach to the analysis of possible tools for migration regulation Russian Federation based on the assessment of the existing world practice. The instrumental and methodical apparatus of the study is based on an integrated approach, within which migration is considered as a goaloriented process that has characteristic components and is influenced by objective and personalized factors that depend on the conditions of the socio-economic situation in the development of the territory, and also combines various methods of scientific knowledge: system analysis, comparative, economic and statistical, grouping, benchmarking, etc. In the course of this study were developed us suggestions to improve the regulation of migration processes in the Russian regions, based on the orientation of the action on the selected specialization and targeted development priorities of the territories.
\end{abstract}

The political and socio-economic development of the modern world moves forward at a rapid pace due to the demands of the information society. Most states are expressing an increasing interest in the measures developed today for the implementation and regulation of migration policy that will become effective for the economy in the very near future.

A contemporary understanding of a region as an independent integral entity, which has its own development goals, resource potential, ways of combining production resources and factors of production, means that there are the regional features in the management of the territory [1]. In this regard, the need to search for tools and methods for regulating migration processes, taking into account the specific objectives and socio-economic conditions, has been mainstreamed.

Recommendations for attracting labor migrants can act as a differentiating boundary between the territorial entity and the migration flow. In this regard, the focus in the

\footnotetext{
*Corresponding author: Grizovskaya.DV@tversu.ru
} 
development of regulatory measures should be directed to objective factors affecting the choice of a region by a migrant, since, other things being equal, qualitative characteristics are not decisive, due to the fact that they are subjectivized by foreign workers.

Another important component is the internal situation in the territory. The needs of the regional economy have a direct impact on the choice of priorities for territorial development, as well as on the situation on the labor market. In this case, the actions of regional authorities can serve as corrective tools, which, when exercising their entrusted powers, must take into account both the federal guidelines of migration legislation and the specific features of socio-economic development of the region in conjunction with the peculiarities of the course of migration processes [2; 3].

The research of K. M. Gubina, M. V. Nemytina, L. Karachurina, M. B., Feldhoff, K. R. Korotkin, E. M. Chichkova, I. A. Skornyakov, G. Yu.Tyumentseva, O. Derkach, V. Bykov is devoted to the problems of regulating the process of attracting workers to the economy of the region. Despite the sufficiently developed issues related to the tools of migration policy, the dynamics of migration processes and methods of their regulation, the authors do not take into account the complexity of socio-economic processes and emerging sociological, historical, demographic and other approaches to the analysis of migration processes, often inconsistent with each other. In addition, the research is carried out without taking into account the differences in the target orientations of the subjects involved in migration regulation, which is a necessary element in making managerial decisions in the migration sphere, since the state, the subjects of the Federation, industrial companies focused on attracting migrant workers, foreign workers and residents of the territory (autochthons) have different, in most cases, contradictory motivating migration motives.

The choice of the region of employment depends on various factors. The attractiveness of a region for a potential applicant is determined according to macroeconomic factors of socio-economic conditions (for instance, migration and labor policy, high-priority development programmes of the region, quality and standard of living) and microeconomic factors associated with the subjective behavioral preferences of a labor migrant, i.e. level of conflict environment in the region, remoteness from place of residence, etc.[4].

According to the methodology of the Federal Service for Labour and Employment (Rostrud), the index of the migratory attractiveness of a region is calculated as the ratio of the region's share in the total gross regional product to the region's population in the total population of Russia

However, in this case, other macroeconomic factors affecting the migration attractiveness of a region are not taken into account. The so-called parameters of regional attractiveness, which, in turn, can be expressed in qualitative and quantitative characteristics.

Thus, the purpose of this study is to develop a mathematical model for assessing the migration attractiveness of a region using multidimensional data representing macroeconomic indicators.

To achieve this goal, it is necessary to solve the following research tasks:

- to determine qualitative and quantitative indicators of the region's attractiveness to foreign labor migrants

- to consider the migration background of a region (on the example of Tver Oblast)

- to analyze the qualitative and quantitative characteristics of the region's attractiveness to foreign labor migrants

- to provide recommendations on using the model to regulate the process of attracting foreign workers to the region.

In recent years Tver Oblast has become one of the most attractive regions for investments in Russia for both Russian and foreign companies. Tver's advantageous geographic location and the economic policy of the region contribute to the dynamic 
development of construction activities, industry, trade, services and, as a result, the labor market in the region.

Tver has location between Moscow and St. Petersburg which provokes an outflow of the young people and skilled human resources to metropolitan areas and abroad, i.e., "brain drain".

The formed territorial structure of the interchange between on the one hand Tver Oblast, and on the other the constituent entities of the Russian Federation and the CIS countries led to the formation of a special educational structure of migration flows. Tver Oblast has a long history of domestic migration of highly qualified population owing to its proximity to metropolitan areas. The influx of labor migrants in recent years has been provided by such countries as Tajikistan, Uzbekistan, Azerbaijan, Kyrgyzstan, etc. It should be noted that a significant part of the arrived labor force is characterized by a lower level of education than that of the local population [1].

Based on the analysis of studies devoted to the regional specifics of the development of labor migration and its regulation, the following quantitative and qualitative indicators were selected as parameters of regional attractiveness for employment of foreign labor force. (figure 1).

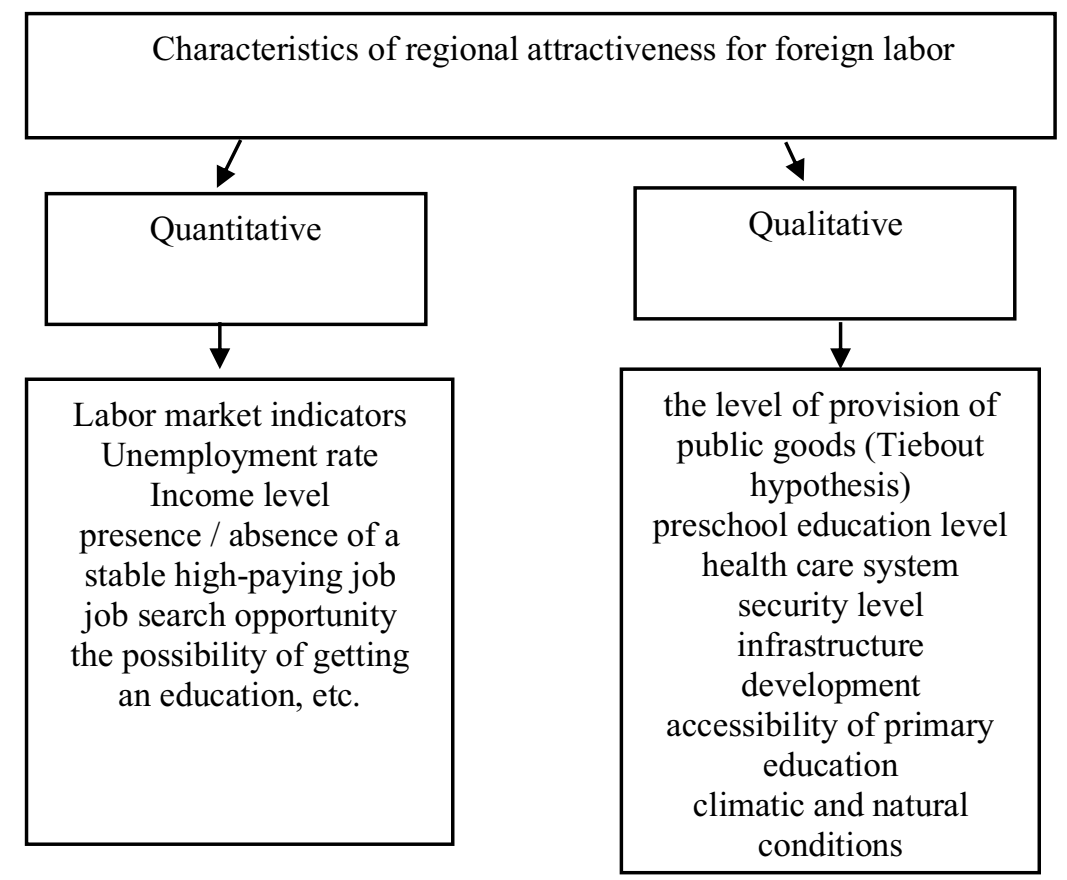

Fig. 1. Characteristics of regional attractiveness for foreign labor.

Theoretical models of factors influencing the migration's flow rate do not reflect the degree of significance of individual indicators on the scale of migration waves. Within the framework of this study, it is proposed to analyze the influence of quantitative indicators on the attractiveness of a region for labor migrants. It should be noted that the quality characteristics will be taken as a constant, due to the fact that they are subjectivizated by foreign workers.

The evaluation of the significance of qualitative characteristics when choosing a region for employment was carried out using the method of expert estimations. The experts were labor migrants of various skill levels, gender, age and nationality. 
The results of the coordination of expert estimations made it possible to conclude that the process of choosing a region by migrants is subjective, which is expressed in a weak consistency of the opinions of experts. It is, however, arguable that there are such equally significant qualitative characteristics of the attractiveness of the region for foreign labor as the health system, the level of security and infrastructure development.

The existing approaches to determining the priority factors affecting the migration's flow rate do not reflect the degree of significance of individual indicators on the scale of migration waves.In order to identify the effectiveness of the migration measures taken by the state, an analysis of the influence of quantitative indicators on the attractiveness of the region for labor migrants was carried out. Qualitative characteristics, other things being equal, are not decisive, due to the fact that they are subjectivizated by foreign workers.

The evaluation of the significance of the characteristics that influence the choice of a migrant's behavior model in determining the region for employment was carried out using the method of expert estimations. The experts were representatives of the scientific community (theoretical approach to assessment) and labor migrants (practical approach to assessment).

Territorial authorities need to analyze and/or identify the "pull factors" of foreign migrants, taking into account the socio-economic and demographic aspects of regional development and in order to prioritize management tools. Indicators, as predictors, are included in a least-square regression, which makes it possible to establish the degree of significance of individual indicators that affect the migration's flow rate (table 1).

Table 1. "Pull factors" of foreign migrants on the example of Tver Oblast

\begin{tabular}{|c|c|c|}
\hline No & Indicator & Rationale for inclusion in the regression model \\
\hline 1 & $\begin{array}{l}\text { Average income per } \\
\text { capita (roubles) }\end{array}$ & $\begin{array}{l}\text { Reflects the ability of the population to attract and pay for the } \\
\text { work and services of labor migrants employed in the informal } \\
\text { economy, i.e. without a written employment contract }\end{array}$ \\
\hline 2 & $\begin{array}{l}\text { Job placements by } \\
\text { the state } \\
\text { employment services } \\
\text { (end of the year), } \\
\text { persons }\end{array}$ & $\begin{array}{l}\text { Reflects the demand in the labor market of Tver Oblast in the } \\
\text { real sector of the economy }\end{array}$ \\
\hline 3 & $\begin{array}{l}\text { The cost of } \\
\text { purchasing a fixed } \\
\text { basket of goods and } \\
\text { service (roubles) }\end{array}$ & $\begin{array}{l}\text { It is one of the indicators of the cost-of-living in the region. } \\
\text { From the point of view of the analysis of labor migration, it } \\
\text { means the possibility of ensuring a positive balance of foreign } \\
\text { migration due to low costs for the purchase of essential goods } \\
\text { and services. }\end{array}$ \\
\hline 4 & $\begin{array}{l}\text { Average prices in } \\
\text { secondary market of } \\
\text { dwelling (roubles) }\end{array}$ & Reflects the affordability of housing for labor migrants \\
\hline 5 & $\begin{array}{l}\text { Average prices in } \\
\text { primary market of } \\
\text { dwelling (roubles) }\end{array}$ & $\begin{array}{l}\text { Reflects the affordability of housing for labor migrants, and is } \\
\text { also a factor that determines the level of income of labor } \\
\text { migrants employed in housing construction }\end{array}$ \\
\hline 6 & $\begin{array}{l}\text { Natural decrease of } \\
\text { population (persons) }\end{array}$ & $\begin{array}{l}\text { Creates a shortage of labor resources in the region both in the } \\
\text { short term (due to the reduction the working-age population) } \\
\text { and in the medium and long term (due to the demographic } \\
\text { hole and the growth of the categories of people unable to } \\
\text { work, taking into account the specifics of the regional } \\
\text { conditions) }\end{array}$ \\
\hline
\end{tabular}


The dependent variable in the regression model was the number of foreign migrants who arrived in Tver Oblast for the period from 2004 to 2018.

Official data from the Territorial Body of the Federal State Statistics Service for Tver Oblast (Tverstat) and the Federal State Statistics Service (Rosstat) were used as sources.

When processing the data in SPSS using the least squares method, the following results were obtained:

- the R-squared value was 0.864 . Thus, a change in the values the predictors mentioned in $86 \%$ of cases leads to a change in the dependent variable, i.e. the number of foreign migrants who arrived in Tver Oblast, which, in turn, testifies to the good quality of the regression model;

- the model is significant (the calculated Fisher criterion was 8.440 with a significance level of 0.04 );

- testing the significance of the parameters of the regression model based on the Student's t-tests showed that the obtained regression coefficients for the explanatory variables "Average income per capita" (coefficient 0.83) and "Natural decrease of population" (coefficient 0.871 ) were statistically significant (table 2).

Table 2. Calculated coefficients of the linear least squares regression (dependent variable is "International migration, number of arrivals")

\begin{tabular}{|c|c|c|c|c|c|}
\hline \multirow[b]{2}{*}{ Model } & \multicolumn{2}{|c|}{$\begin{array}{c}\text { Unstandardized } \\
\text { regression coefficients }\end{array}$} & \multirow{2}{*}{\begin{tabular}{|c|}
$\begin{array}{c}\text { Standardized } \\
\text { regression } \\
\text { coefficients }\end{array}$ \\
Beta
\end{tabular}} & \multirow[b]{2}{*}{$\begin{array}{l}\text { Student's } \\
\text { t-tests }\end{array}$} & \multirow[b]{2}{*}{ Significance } \\
\hline & B & $\begin{array}{c}\text { Standard } \\
\text { error }\end{array}$ & & & \\
\hline (Constant) & 22933,977 & 9068,312 & & 2,529 &, 035 \\
\hline $\begin{array}{l}\text { Average income per } \\
\text { capita (roubles) }\end{array}$ & ,830 & ,738 & 3,616 & 1,125 & ,293 \\
\hline $\begin{array}{l}\text { Job placements by the } \\
\text { state employment } \\
\text { services (end of the } \\
\text { year), persons }\end{array}$ &,- 004 & , 143 &,- 006 &,- 029 & ,977 \\
\hline $\begin{array}{l}\text { The cost of purchasing } \\
\text { a fixed basket of goods } \\
\text { and service (roubles) }\end{array}$ & $-1,944$ & 1,374 & $-4,366$ & $-1,415$ & , 195 \\
\hline $\begin{array}{l}\text { Natural decrease of } \\
\text { population (persons) }\end{array}$ & ,871 & ,363 & 1,940 & 2,399 & ,043 \\
\hline $\begin{array}{l}\text { Average prices in } \\
\text { secondary market of } \\
\text { dwelling (roubles) }\end{array}$ &,- 146 & , 157 & $-1,038$ &,- 932 & ,379 \\
\hline $\begin{array}{l}\text { Average prices in } \\
\text { primary market of } \\
\text { dwelling (roubles) }\end{array}$ & ,078 &, 111 & ,530 & ,707 &, 500 \\
\hline
\end{tabular}

The use of the data from Tver Oblast for the period from 2004 to 2018 in order to test that model made it possible to determine the average income per capita of the population and the natural decrease of population as significant indicators, which is expressed in the following trends:

- when increasing the average income per capita by 10 roubles the number of foreign migrants, according to the results obtained, increases by 8 people;

- when decreasing the population of Tver Oblast by 10 people, the number of foreign migrants increases by 8-9 people, which is due to the acceleration of population ageing. 
A basic tool in regulating migration processes in Tver Oblast and reducing imbalances in the labor market is the priority of the indigenous population over migrants in employment. So, in 2016, on the initiative of the Governor of Tver Oblast the quota migrant labor was reduced, the cost of a valid patent to perform labour activities for foreign citizens was increased from 3.5 thousand roubles to 5 thousand roubles, and a ban has been put on the use of migrant labor in 22 types of economic activities. This list includes forestry and wood processing, with the exception of the services of laborers, the production of beer and alcoholic beverages and alcohol, the construction of hydraulic structures, the production of rubber and plastic products, etc.

It should be noted that the growth in the cost of a $p$ atent to perform labor activities for foreign citizens does not correlate with the forecast indicators of the average monthly wage in the region for 2018, which is expected to grow in the range of 4.2-5.0\%. According to the Forecast of the Socio-Economic Development of Tver Oblast for 2018 and for the planning period of 2019, approved by the Order of the Government of Tver Oblast in 2016, the nominal average monthly wages per person will be about 27,400 roubles, which means that the personal income tax will be approximately equal to 3,562 roubles. Based on the foregoing, it follows that the specified increase fixed advance payment amount for personal income tax of foreign citizens, seems economically unjustified.

A positive consequence of the ongoing migration measures can be considered an increase by $21.7 \%$ of patents issued, which may indicate the intensification of the processes of legalization of foreign labor and the economic adaptation of labor migrants to the current requirements of an assimilation migration policy.

However, the measures taken can lead to an increase in illegal employment of migrants, as well as an increase in applications for obtaining Russian citizenship, and the problem of unpopular jobs for the locals remains.

The migration approach to attracting foreign workers should include organizational and conceptual-theoretical components.

In this regard, the authors believe that the use of a functional-level planning organization seems to be the most appropriate and effective. This component contains the stages necessary for making a managerial decision in the migration sphere. The decomposition structure of the component is as follows.

1. Research level which includes

- the development of a unified methodology;

- the study of migration processes and identification of regional specifics;

- the definition of qualitative and quantitative indicators of migration.

This level is necessary to identify acute migration problems both at the regional and federal levels in order to prioritize migration accents, and to analyze international practices for resolving the identified contradictions.

2. Information level which includes

- GIS monitoring of labor migration [5; 6];

- the systematization of statistical information [5;6];

- the development of employment barometers;

- making data available [5].

The need for this level is due to the disjointed statistical data on the constituent entities of the Russian Federation, the inaccessibility of up-to-date information on the labor market and the lack of information support for the regulation of migration processes.

1. Management level which includes

- the preparation of a strategic plan for migration development;

- the distribution of powers between the performers of the strategy;

- the organization of procedures for working with migrants. 
The proposed structure can be considered as a basis for choosing methods of migration regulation and determining a strategic goal.

The conceptual and theoretical component includes the development of qualitatively important elements of migration regulation in the existing socio-economic conditions for the development of the country and the region.

First, the use of a differentiated method of accepting labor migrants based on a competence-based and goal-oriented approach. In this regard, it is advisable to use the successful practice of implementing the economic forecasting of the demand for competencies in the labor market in the form of employment barometers [5].

In the context of the current socio-economic situation in the region, such a forecasting system should be based on the interests of all market participants, for example, governing bodies, employers, employees, educational institutions, etc.

These actors represent an expert survey panel. The roadmap for the survey is the following:

- interviewing enterprises / organizations of the reviewed industry;

- determination of the needs for professional training of labor resources, priority skills and abilities, etc.;

- formulation of recommendations for the development of the selected sector;

- organizing the interaction of survey participants at the regional and municipal levels;

- dissemination of the obtained data among all stakeholders [5].

When compiling questionnaires, it is necessary to keep the range of questions to a minimum, selecting only those that reflect the most important factors affecting the chosen industry.

This interview provides additional information on trends and prospects for the development of the labor market or a specific industry. Based on the data obtained during the survey, a monthly employment barometer is formed.

This tool for regulating labor migration allows solving several problems at once: vocational guidance, enhancing labor mobility, analyzing the state of the labor market (deficit-surplus of professions), as well as forecasting and planning immigration, and providing consulting services to employers in new territories.

To implement this proposal, it is necessary to create a regional Employment and Economic Development Bureau, whose employees will have a deep understanding of the situation on the labor market, based on periodic interviews and surveys of employers, direct communication with clients of the employment service [6].

The demand for competencies is a tool for selecting labor migrants according to the level of their qualifications and motivation for development.

Secondly, the conceptual and theoretical component should include criteria for determining highly qualified personnel.

At the moment the main indicator of the high qualifications of foreign workers in Russia is the level of wages, which is not a representative selection criterion.

The proposed comprehensive goal-oriented migration approach to assessing the directions of regulating the process of attracting the working-age foreign migrants to the region is based on the strategy of attracting highly qualified personnel using labor market defragmentation by identifying a shortage / surplus of labor in a particular segment of economy.

So, the unified criteria and indicators for determining highly qualified personnel among labor migrants are the following:

1.level of education

- degree obtained as a result of training;

- cumulative duration of training. 
2. the profession (for which the application is submitted) is on the state list of professions in demand;

3.professional experience [5]

- feedback from employers;

- level of employment (full-time, part-time, etc.)

- work experience in the chosen profession or in a related field.

4. the size of the minimum annual gross salary (depending on the region) $[7 ; 8]$.

5.scientific, technical and intellectual achievements

- availability of a patent for an object of intellectual property;

- number of individual / corporate grant research.

6. integration potential

- knowledge of the language and cultural foundations of the country of entry;

- degree of tolerance;

- motivation and readiness to work in a foreign cultural environment.

For each assessment criterion, a minimum level of points may be provided for obtaining the status of a highly qualified specialist and the right to work. The total number of points received by a foreign citizen according to all assessment criteria serves both as the basis for obtaining the status of a highly qualified specialist and determines the chances of finding a job.

The use of a regulated system for assessing the level of qualifications of a foreign worker will allow solving the problem of imbalance in the labor market and contributes to improving the quality of labor resources, as well as the accumulation of human capital by coordinating the targets of the subjects of the migration process.

The specificity of the socio-economic and migration processes of the region and the sectoral segments of the territorial labor market will make it possible to rank these criteria, highlighting the priority and most indicative for this sector and territories.

\section{References}

1. Ju. Andrienko, S.Guriev, Development of a model of internal and external migration flows of the population for the regions of the Russian Federation (CEFIR, Moscow, 2006)

2. N.Bullejn, R.Toftisova, Comparative analysis of European policy and practice in the field of cooperation between the State and NGOs (ICNL, Kiev, 2005).

3. M.B.Gorny, JSPS, 9, 2. P. 219-232, (2011).

4. N.V. Melihova, Vestnik.econri, 3, P. 292-297, (2005)

5. A. A. Jakovleva, Demand and supply in the labor market and the market of educational services in the regions of Russia, 3, P. 312-321, (2011)

6. B. Ov-Frajtag 3, J. MSPS, 4 (50), (2009). https://otetrad.ru/article-500.html

7. R. Heinze, J. Schmid, Ch. Strunck, KZFSS.UNI, 49, 2, (1997)

8. S. Lavenex, R. Kunz, Journal of European Integration, 30, P. 439-457, (2008) 